The University of Maine

DigitalCommons@UMaine

$1-22-2014$

\title{
Habitat occupancy of Rusty Blackbirds (Euphagus carolinus) breeding in northern New England, USA
}

Luke L. Powell

Thomas P. Hodgman

lan J. Fiske

William E. Glanz

Follow this and additional works at: https://digitalcommons.library.umaine.edu/bio_facpub

Part of the Natural Resources and Conservation Commons, and the Ornithology Commons

This Article is brought to you for free and open access by DigitalCommons@UMaine. It has been accepted for inclusion in Biology and Ecology Faculty Scholarship by an authorized administrator of DigitalCommons@UMaine. For more information, please contact um.library.technical.services@maine.edu. 


\title{
Habitat occupancy of Rusty Blackbirds (Euphagus carolinus) breeding in northern New England, USA
}

\author{
Luke L. Powell, ${ }^{1, a *}$ Thomas P. Hodgman, ${ }^{2}$ lan J. Fiske, ${ }^{3}$ and William E. Glanz ${ }^{1}$ \\ 1 School of Biology and Ecology, University of Maine, Orono, Maine, USA \\ 2 Maine Department of Inland Fisheries and Wildlife, Bangor, Maine, USA \\ ${ }^{3}$ Department of Statistics, North Carolina State University, Raleigh, North Carolina, USA \\ ${ }^{a}$ Current address: Migratory Bird Center, Smithsonian Conservation Biology Institute, National Zoological Park, Washington, DC, USA \\ * Corresponding author: Luke.L.Powell@gmail.com
}

Received July 7, 2013; Accepted September 11, 2013; Published January 22, 2014

\begin{abstract}
The Rusty Blackbird (Euphagus carolinus), an uncommon songbird often associated with northern coniferous wetlands, has experienced a precipitous population decline since at least the early 20th century. Here, we provide the first analysis of breeding-habitat occupancy at the wetland scale and make recommendations for streamlined monitoring. We modeled occupancy and detectability as a function of site (i.e. habitat-based) and sampling (i.e. visit-specific) variables collected at 546 wetlands in northern New England, USA. Wetland occupancy (mean \pm SE $=0.07 \pm 0.02$ in randomly selected wetlands, and $0.12 \pm 0.02$ in all wetlands surveyed) was best explained by variables describing Rusty Blackbird foraging habitat (PUDDLES: a proxy for shallow water), nesting habitat (coniferous adjacent uplands), and evidence of beavers. In contrast to Rusty Blackbirds' selection of pole-stage conifers at the nest-site scale, stand age did not affect occupancy at the wetland scale. It appears that most wetlands in northern coniferous forest landscapes, regardless of stand age, offer dense conifer patches nearby and provide suitable breeding habitat if quality foraging sites (e.g., areas of shallow water) also are available. Detectability $(0.29 \pm 0.04)$ decreased with increasing wind speed, and decreased about fourfold over the course of the breeding season. Rusty Blackbirds responded to broadcast of conspecific vocalizations by flying toward the observer and perching more often than prior to broadcast, demonstrating that broadcasts can be a useful tool to enhance visual detectability. Given our results, observers can now focus site selection on wetlands and sampling conditions most likely to maximize detections of Rusty Blackbirds.
\end{abstract} Keywords: boreal wetlands, broadcast experiment, detectability, Euphagus carolinus, monitoring, occupancy, Rusty Blackbird

\section{Occupation de l'habitat par Euphagus carolinus nichant dans le nord de la Nouvelle-Angleterre, aux États-Unis RÉSUMÉ}

Euphagus carolinus, un oiseau chanteur peu commun souvent associé aux milieux humides conifériens nordiques, a connu un déclin précipité de ses populations depuis au moins le début du $20^{\mathrm{e}}$ siècle. Nous fournissons ici la première analyse de l'occupation de l'habitat de reproduction à l'échelle du milieu humide et faisons des recommandations pour un suivi simplifié. Nous avons modelé l'occupation de l'habitat et la détectabilité comme une fonction du site (i.e. basé sur l'habitat) et des variables d'échantillonnage (i.e. spécifique à la visite) recueillies dans 546 milieux humides du nord de la Nouvelle-Angleterre, aux États-Unis. L'occupation des milieux humides (moyenne $\pm \mathrm{SE}=0.07 \pm 0.02$ dans les milieux humides sélectionnés aléatoirement et $0.12 \pm 0.02$ dans tous les milieux humides inventoriés) était davantage expliquée par les variables décrivant l'habitat d'alimentation d'E. carolinus (PUDDLES: un terme représentant l'eau peu profonde), I'habitat de nidification (milieux secs conifériens adjacents) et la présence de castors. Contrairement à la sélection par E. carolinus de conifères au stade de perchis à l'échelle du site de nidification, l'âge du peuplement n'affectait pas l'occupation à l'èchelle du milieu humide. II semble que la plupart des milieux humides dans les forêts conifériennes nordiques, sans égard à l'âge du peuplement, offrent des parcelles de conifères denses à proximité et fournissent un habitat de reproduction propice si des sites d'alimentation de qualité (e.g., zones d'eau peu profonde) sont aussi disponibles. La détectabilité $(0.29 \pm 0.04)$ diminuait avec l'augmentation de la vitesse du vent et diminuait d'environ quatre fois au cours de la saison de reproduction. E. carolinus répondait à la repasse de chants de ses congénères en volant vers l'observateur et en se perchant plus souvent qu'avant cette émission, ce qui démontre que la repasse de chants peut être un outil utile pour augmenter la détectabilité visuelle. Compte tenu de nos résultats, les observateurs peuvent maintenant concentrer la sélection des sites sur les milieux humides et les conditions d'échantillonnage les plus susceptibles de maximiser les détections d'E. carolinus.

Mots-clés: milieux humides boréaux, expérience de repasse de chants, détectabilité, Euphagus carolinus, suivi, occupation. 


\section{INTRODUCTION}

Declining population trends of migratory birds, especially in eastern North America (Sauer and Droege 1992), provided much of the impetus for bird conservation since the mid-1990s. Through the actions of Partners in Flight (Rich et al. 2004), the North American Bird Conservation Initiative (U.S. NABCI Committee 2000), and key conservation organizations (e.g., American Bird Conservancy, Cornell Laboratory of Ornithology, and Rocky Mountain Bird Observatory), species were first prioritized to identify those needing attention (Carter et al. 2000). More recently, with the help of State Wildlife Grants, agencies and organizations have begun the arduous tasks of understanding what drives populations of many of these formerly poorly studied species and developing programs to assist in recovery. During this process, a number of species quickly rose to the top of the list for conservation action. In the northeastern USA, species like Bicknell's Thrush (Catharus bicknelli) and Saltmarsh Sparrow (Ammodramus caudacutus) became the focus of research and conservation (Atwood et al. 1996, Greenberg et al. 2006, Townsend et al. 2009), often owing to the large percentage of the global population in that region. The Cerulean Warbler (Setophaga cerulea) became emblematic of Neotropical migrants needing conservation efforts both in North America and on its wintering grounds in the Andes (Robbins et al. 1992, Rosenberg et al. 2008). The Rusty Blackbird (Euphagus carolinus), though widely distributed continentally, has suffered a precipitous longterm decline (Greenberg and Droege 1999, Niven et al. 2004), but of late has been the focus of much research on

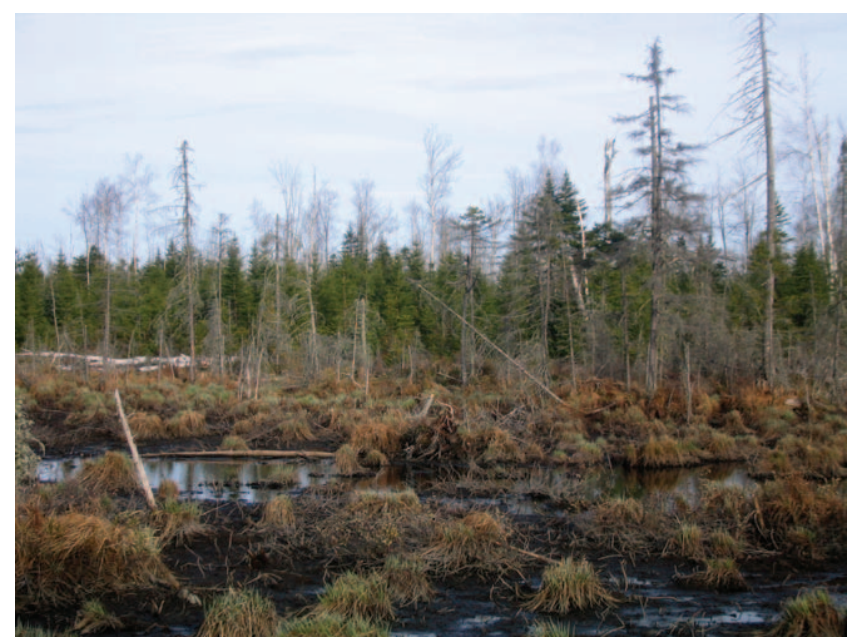

FIGURE 1. Typical Rusty Blackbird breeding habitat in New England as seen in mid-May prior to leaf-out. Foraging habitat (i.e. shallow water and puddles) is visible in the foreground, while nesting habitat (i.e. thick, short spruce and fir) can be seen in the background. both breeding and wintering grounds (e.g., Greenberg and Matsuoka 2010).

The Rusty Blackbird is a migratory songbird that breeds in northern conifer-dominated forests often associated with a variety of wetland types typical of boreal and Acadian forests (Figures 1 and 2). Although population declines are well documented in this now uncommon species (Greenberg and Droege 1999, Niven et al. 2004, Sauer et al. 2005), few studies have quantified breeding habitat at small spatial scales (Buckley 2013) and most information is based on anecdotal accounts, breeding bird atlas records, and government reports. From the information available, it is clear that Rusty Blackbirds use swampy woodlands (Laughlin and Kibbe 1985), fens (Avery 1995), bogs (Peterson 1988, Erskine 1992), damp alder swales (Erskine 1992), and beaver-influenced wetlands (Ellison 1990, Foss 1995). Rusty Blackbirds in the northeastern USA nest primarily in young spruce and fir trees (Kennard 1920, Ellison 1990, Powell et al. 2010b, Buckley 2013), often in stands regenerating from timber harvest, seemingly well away from large wetlands. Although Rusty Blackbirds forage in wetlands and consume aquatic prey (Beecher 1951, Ellison 1990, Avery 1995), it remains unclear what habitat characteristics influence occupancy.

There are so few encounters of Rusty Blackbirds on the Breeding Bird Survey and during state atlas projects that population trend estimates are not reliable for the northeastern USA and the Maritime Provinces of Canada (Erskine 1977, Sauer et al. 2005). At the continental scale,

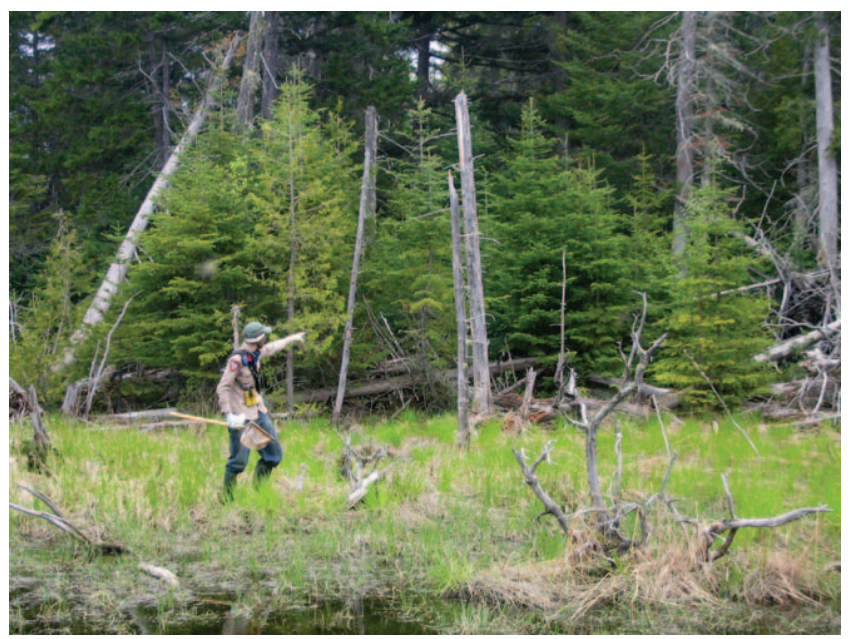

FIGURE 2. Research technician James Osenton points to a Rusty Blackbird nest located about $1.5 \mathrm{~m}$ high in the thick fir to the right of the double-snag. Here a beaver impoundment had created foraging habitat for the species (i.e. shallow water; foreground) within a stand of mostly mature spruce and fir (background). Water level had dropped since the initial impoundment of the creek, creating a drier patch of perhaps 25 thick young conifers in which the Rusty Blackbirds nested (midground). 
Rusty Blackbird populations have declined by $85 \%$ (Sauer et al. 2004) to $>95 \%$ (Sauer et al. 2005) since 1966, and there is strong qualitative evidence for population declines dating back at least 100 years (Greenberg and Droege 1999). The species' range has contracted by $160 \mathrm{~km}$ in Maine since 1983 (Powell 2008), but the lack of contemporary data makes it difficult to determine whether declines are ongoing. Causes of the decline are unknown, although the loss of wooded wetlands on nonbreeding grounds in the southeastern USA is a likely contributor (Greenberg and Droege 1999). On the breeding grounds, timber management (Powell et al. 2010b), road construction, changes in wetland hydrology (Klein et al. 2005), competition with other icterids (Ellison 1990, Erskine 1992), and mercury accumulation (Edmonds et al. 2010) have all been hypothesized as contributing to the species' decline.

Here, we use an occupancy framework to quantify Rusty Blackbirds' habitat use at the wetland scale and, using our findings, we make recommendations to streamline future efforts to locate meaningful numbers of the species. Given the species' nesting and foraging habits, we hypothesize that wetland occupancy is linked to (1) coniferous growth in and adjacent to wetlands and (2) indicators of shallow water (e.g., puddles, mud). Our primary objectives were to provide the first analysis of breeding-habitat occupancy at the wetland scale and to use the results of our detectability and occupancy analyses to provide recommendations to improve efficiency of monitoring efforts for this uncommon yet widely distributed species. Secondarily, we examined behavior of Rusty Blackbirds following broadcast of conspecific vocalization to determine whether detectability could be improved by this simple technique.

\section{METHODS}

\section{Study Area}

We conducted our study in northern and western Maine and northeastern Vermont, USA (Figure 3). Our northern Maine sites occurred in a largely uninhabited and relatively flat industrial forest landscape, within which we surveyed mostly low-elevation wetlands adjacent to coniferous forests of varying ages. Few wetlands in northern Maine were protected from timber harvest by riparian buffers during the 1970s and 1980s, when many wetlands were subjected to clear-cut or partial harvests to their edges or within their boundaries. Forest type and management in western Maine and northeastern Vermont were similar but, unlike in northern Maine, characterized by small-scale timber operations. In Vermont, rural communities perforate a landscape with considerably more topographic relief than in northern Maine. From the ground, we estimated that most wetlands we surveyed were in the 0.5 to 2 ha range, although size varied from about 0.1 ha to about 10

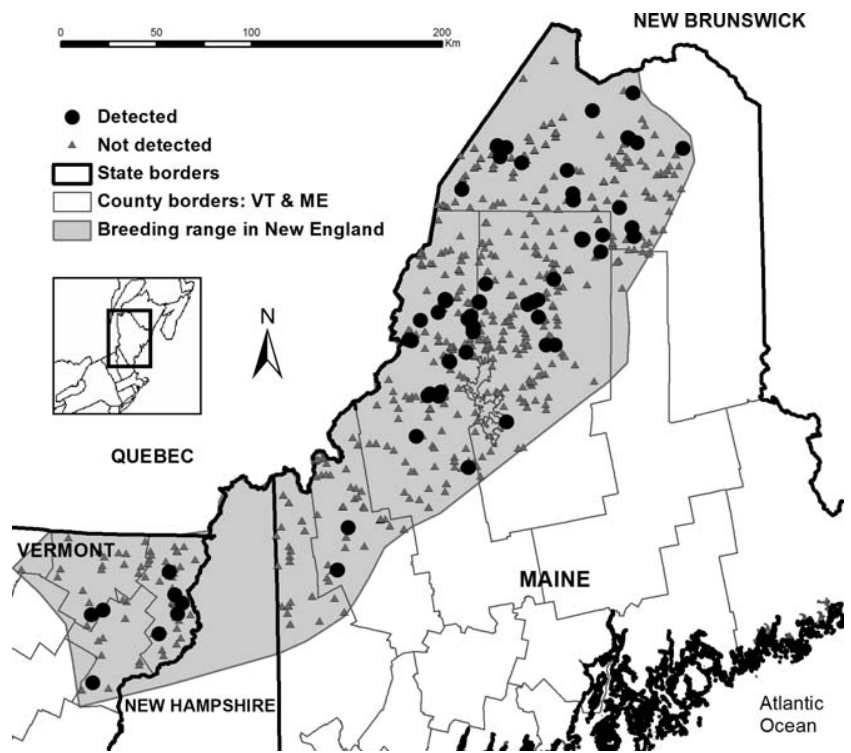

FIGURE 3. Map of Rusty Blackbird surveys in 546 wetlands in Maine and Vermont, USA, 2006-2007.

ha. We surveyed a variety of wetland types, including bogs, wooded fens, alder (Alnus incana) swamps, cattail (Typha latifolia) marshes, and flowages created by American beaver (Castor canadensis). Black spruce (Picea mariana), red spruce ( $P$. rubens), balsam fir (Abies balsamea), northern white cedar (Thuja occidentalis), quaking aspen (Populus tremuloides), paper birch (Betula papyrifera), red maple (Acer rubrum), speckled alder, and Sphagnum spp. were the dominant species in surrounding forests.

\section{Sampling Design}

We performed point counts for breeding Rusty Blackbirds at 546 wetlands from 29 April to 27 June in 2006 and 2007. All 546 wetlands were within the Rusty Blackbird's current breeding range (Figure 3; Greenberg et al. 2011) as defined by Powell (2008). Because of time constraints, we only surveyed wetlands in which wetland vegetation (typically alder or standing dead cedars) was visible from roads. Our sampling units, which we define as wetland-scale, were restricted to what we could see and hear (and what the birds could hear, i.e. broadcast) from a single point-count location from a road at the edge of a wetland.

We used results of these surveys to model occupancy and detectability. We selected wetlands for survey on the basis of four approaches, as denoted by the variable CHOICE (Table 1). For $\mathrm{CHOICE}_{\text {Literature, we drove }}$ accessible forest roads and selected 352 wetlands in the field on the basis of descriptions of suitable habitat (Ellison 1990, Avery 1995, Hodgman and Hermann 2003) and our previous field experience with Rusty Blackbirds in Maine. $\mathrm{CHOICE}_{\mathrm{Literature}}$ wetlands had at least some short coniferous vegetation (nesting habitat) and some visible 
TABLE 1. Variables used to model detectability and habitat occupancy of Rusty Blackbirds in Maine and Vermont, USA, $2006-2007$.

\begin{tabular}{|c|c|}
\hline Variable & Description $^{a}$ \\
\hline \multicolumn{2}{|l|}{ Site variable } \\
\hline BEAVER & Current evidence of beaver activity, including freshly chewed wood, scat, or an actively maintained dam \\
\hline CHOICE & $\begin{array}{l}\text { Categorical variable; denotes whether wetland was selected on the basis of literature }\left(\mathrm{CHOICE}_{\mathrm{Literature}}\right) \text {, by } \\
\text { stratified random design }\left(\mathrm{CHOICE}_{\text {Random }}\right) \text {, because it was previously occupied by Rusty } \\
\left.\text { Blackbirds(CHOICE } \mathrm{Cld}_{+}\right) \text {, or because of an opportunistic encounter of Rusty Blackbirds while driving } \\
\text { between sites }\left(\mathrm{CHOICE}_{\text {Driveby }}\right)\end{array}$ \\
\hline HARVEST5TO15 & Upland was harvested between 5 and 15 years prior \\
\hline MUD & Presence of any mud in or adjacent to the wetland \\
\hline PUDDLES & Presence of shallow water not contiguous with open or flowing water \\
\hline ROAD & $\begin{array}{l}\text { Four ordinal categories: unimproved dirt road, little-used improved dirt road, well-used improved dirt } \\
\text { road, paved road }\end{array}$ \\
\hline SOFTWD_UP & Adjacent upland $>70 \%$ softwood; binary \\
\hline WETAREA $\bar{b}^{\mathrm{b}}$ & $\begin{array}{l}\text { Four wetland area categories (ha) as estimated by the observer from the survey location: }<0.1,0.1-0.5 \text {, } \\
0.6-2.0,>2.0\end{array}$ \\
\hline YNGSF & Presence of spruce or fir $<3 \mathrm{~m}$ tall within wetland \\
\hline \multicolumn{2}{|l|}{ Sampling variable } \\
\hline DATE & Julian day/100 \\
\hline MIN & Minute of day at which survey began \\
\hline BROADCAST & $\begin{array}{l}\text { Categorical variable allowing detectability to vary among survey intervals before ( } 3 \mathrm{~min}) \text {, during (38 s), } \\
\text { and after ( } 5 \mathrm{~min}) \text { broadcast of Rusty Blackbird vocalization }\end{array}$ \\
\hline PRECIP & Binary measure of precipitation during survey \\
\hline SHRUB & Percentage of the wetland vegetation composed of shrubs $(<2 \mathrm{~m})$ \\
\hline SKY & Three categories: $<10 \%$ clear, $11-90 \%$ clear, $>90 \%$ clear \\
\hline WIND & $\begin{array}{l}\text { Mean wind index during survey (continuous): } 0=\text { no wind }\left(<1 \mathrm{~km} \mathrm{~h}^{-1}\right), 1=\text { leaves rustle gently }(1-5 \\
\left.\mathrm{km} \mathrm{h}^{-1}\right), 2=\text { feel wind on face }\left(6-11 \mathrm{~km} \mathrm{~h}^{-1}\right), 3=\text { wind clogs one ear }\left(12-19 \mathrm{~km} \mathrm{~h}^{-1}\right), 4=\text { wind } \\
\text { clogs both ears }\left(20-29 \mathrm{~km} \mathrm{~h}^{-1}\right)\end{array}$ \\
\hline YEAR & Binary variable: whether the survey was performed in 2006 (i.e. not 2007) \\
\hline
\end{tabular}

${ }^{a}$ All variables estimated by the observer from the survey point.

${ }^{\mathrm{b}}$ Run as both a site and a sampling variable.

shallow water (i.e. foraging habitat). However, to better represent the variability of wetlands across the landscape, in 2007 we added 143 wetlands in northwestern Maine and northeastern Vermont that we selected using a geographically stratified random design ( $\left.\mathrm{CHOICE}_{\text {Random }}\right)$; we identified those wetlands using a digital copy of the National Wetlands Inventory layer (Cowardin et al. 1979). If a randomly selected site was obviously unsuitable upon first visitation (e.g., no coniferous nesting habitat, no open water), we surveyed the next nearest wetland that appeared suitable. To increase our detections and, thus, our predictive power, we also surveyed 46 wetlands that, according to the best available information (anecdotal reports from birders; Hodgman and Hermann 2003, Sauer et al. 2005), were previously occupied by Rusty Blackbirds $\left(\mathrm{CHOICE}_{\mathrm{Old}+}\right)$. Finally, we included six sites on the basis of opportunistic detections of Rusty Blackbirds when driving between sites ( $\left.\mathrm{CHOICE}_{\text {Driveby }}\right)$.

During the 2006 season, we conducted one survey per wetland. After this first field season, it became clear that occupancy modeling was rapidly becoming the preferred technique to model presence-absence of animals in discrete habitat patches (MacKenzie et al. 2006); accordingly, in the 2007 season, we performed multiple surveys at a random subset of wetlands to estimate detectability (Table 2). Each survey included $3 \mathrm{~min}$ of passive observation followed by a prerecorded 38-s broadcast of a male Rusty Blackbird vocalization and then $5 \mathrm{~min}$ of passive observation. The broadcast, recorded in New York State, consisted of $\sim 90 \%$ male songs and call (chek) notes and $\sim 10 \%$ garbled chatter (Avery 1995). We broadcasted the recorded vocalization using a Predation MP3 Game Caller (Western Rivers, Lexington, Tennessee) with the volume set to 20 , resulting in a broadcast $\sim 30 \%$ louder than vocalizations of live birds. During each survey interval (i.e. before, during, and after broadcast), we recorded detections and behavior of Rusty Blackbirds.

Following each point count, we recorded site (i.e. habitat) and sampling (i.e. visit-specific) variables (Table

TABLE 2. Number of visits by year to each of 546 wetlands in Maine and Vermont, USA, 2006 and 2007.

\begin{tabular}{lccc}
\hline & \multicolumn{3}{c}{ Number of visits } \\
\cline { 2 - 4 } Year & 1 & 2 & 3 \\
\hline 2006 & 251 & 0 & 0 \\
2007 & 223 & 22 & 50 \\
\hline
\end{tabular}


1). We selected site variables that we thought would affect habitat selection on the basis of descriptions in the literature (Kennard 1920, Ellison 1990, Avery 1995, Hodgman and Hermann 2003) and our previous field experience with the species. Specifically, we recorded site variables indicative of shallow-water foraging habitat (MUD, PUDDLES, and BEAVER) and area of foraging habitat (WETAREA), indicators of nesting habitat (HARVEST5to15, SOFTWOOD_UP, YNGSF), and the class of road (e.g., primary or secondary) we were surveying from (ROAD). We used 5 to 15 years old as the age class for HARVEST5to15 because this seemed the appropriate age for nesting habitat according to the literature and our experience finding nests in 2006 . We arbitrarily used $>70 \%$ softwoods in the adjacent uplands as the cutoff for SOFWOOD_UP. We documented sampling variables that we believed would decrease detectability (PRECIP, SHRUB, SKY, WIND, DATE, MIN). We also added BROADCAST, a variable that allowed detectability to vary among survey periods. This variable included the combined effects of conspecific broadcast and survey period length. We surveyed during all daylight hours in 2006 but detected few individuals during midday (Powell 2008); accordingly, we did not survey from 1100 to 1600 hours in 2007. We did not survey in heavy rain or strong wind $\left(>\approx 25 \mathrm{~km} \mathrm{~h}^{-1}\right)$.

\section{Modeling Occupancy and Detectability}

We modeled Rusty Blackbird occupancy $\left(\psi_{i}\right)$ as a function of site characteristics affecting presence-absence, contingent on site and sampling covariates affecting detectability (MacKenzie et al. 2002), using the package UNMARKED (Fiske and Chandler 2010) in Program R (R Development Core Team 2009). Our general strategy was to formulate a candidate set of models describing detectability $(p)$, select a best-fit model, then use that best-fit detectability model as the base model in the candidate set of occupancy models.

We used several statistical adjustments to account for our unique sampling design using UNMARKED. We used a "single-season" occupancy models (MacKenzie et al. 2006), with 2 years worth of data collapsed into 1 year. To account for potential year effects, we included YEAR in the occupancy candidate set as a site variable. To conform to the data structure required for "single season" models, in the handful of cases in which we surveyed the same wetland in both years, we used only the data from 2007. Rather than discard our single-visit data set from 2006 (Table 2), we pooled it with our multiple-visit dataset from 2007, treated the second and third visits in 2006 as missing data, and developed models under the assumption that detectability did not vary between 2006 and 2007. Sites that we selected because of opportunistic sightings of Rusty Blackbirds $\left(\mathrm{CHOICE}_{\text {Driveby }}\right)$ were obviously occupied; hence, to avoid biasing our overall estimates of occupancy, we fixed occupancy of those six sites to 1.0. To avoid potential errors associated with values much greater than zero, we transformed sampling variables with large values by dividing by 100 . We treated each sampling interval (BROADCAST $\mathrm{B}_{\text {before }}, \mathrm{BROADCAST}_{\text {during, }}$, BROADCAST $_{\text {after }}$ ) as a separate visit, simultaneously accounting for the difference in use of a prerecorded broadcast and length of survey intervals by modeling each survey interval separately as a unique categorical variable (A. Royle, Patuxent Wildlife Research Center, personal communication). We were able to treat those consecutive sampling intervals as separate visits because in occupancy modeling, all detections at a site are modeled conditionally on the latent occupancy state of the site. Thus, correlation among detection methods (treated as separate visits in the model) is implicit in the hierarchical occupancy model because all visits depend on the same $\psi_{i}$.

To model Rusty Blackbird detectability, we formulated 18 a priori models that included combinations of the eight variables that we hypothesized were affecting detection probability (Table 1). Because one of our goals was to make recommendations for monitoring that maximize species detections, we were particularly interested in testing hypotheses that detectability decreased over the course of the season (DATE) as males became less territorial, or decreased over the course of the day (MIN), so we included additive combinations of those variables that we believed were biologically plausible. We included two quadratic models to test the alternative hypotheses that (1) detectability was highest near dawn and dusk $\left(\mathrm{MIN}^{2}\right)$ and (2) birds were most detectable early in the season (when males were strongly territorial) and again late in the season (when fledglings were vocal and volant; $\mathrm{DAY}^{2}$ ). Other variables that we suspected would decrease detectability (WIND, SKY, PRECIP, SHRUB, WETAREA) were included in univariate models and as part of nested models with BROADCAST, DATE, and MIN. Finally, we suspected negative interactions between WETAREA and BROADCAST as well as WETAREA and WIND, so we included two bivariate interactive models.

To model wetland occupancy, we first used the literature on breeding Rusty Blackbirds (Kennard 1920, Laughlin and Kibbe 1985, Ellison 1990, Erskine 1992, Avery 1995) and our own field observations to compile a candidate set of 15 a priori models. We used the detectability model with the lowest Akaike's Information Criterion (AIC) value (the "best-fit" model) as the base detection model for all occupancy models. We believe that the Rusty Blackbird is inherently a wetland bird and that, at the wetland scale, Rusty Blackbird occupancy is driven primarily by selection for foraging habitat (i.e. shallow water high in invertebrates; Avery 1995) and nesting habitat (i.e. coniferous growth; Ellison 1990), so all occupancy models were what we believed to be biologically plausible combinations of foraging and nesting habitat. Beavers can create both 
nesting habitat (by selectively eating hardwoods; Johnston and Naiman 1990) and foraging habitat (through flooding; McDowell and Naiman 1986), so $\psi$ (BEAVER) was our only univariate occupancy model. To test for year effects, we created nested models by repeating combinations of habitat in two models, adding only YEAR. Finally, we wondered whether the disturbance caused by larger, more heavily used roads decreased Rusty Blackbird occupancy, so again we added ROAD to otherwise identical habitat models.

We ranked the fit of models using AIC and considered models with $\triangle$ AIC values $<2$ as those with substantial support (Burnham and Anderson 2002). We assumed, a priori, that occupancy varied among wetlands selected (1) for apparent suitability, (2) with a stratified random design, and (3) on the basis of opportunistic sightings, so we included the categorical variable CHOICE as the base model for all models in the study. We checked for correlations among explanatory variables with Spearman's rank correlation test and avoided using correlated variables $(P<0.05)$ in the same model. We used AIC to select models that best described occupancy and detectability. In the few cases in which we had missing data (e.g., one category was omitted on the data sheet), we replaced missing values for continuous and binary variables with the mean and categorical variables with the mode. When model-averaging, we used all models in the candidate set for occupancy. We evaluated model fit of the global models for occupancy and detectability using a goodness-of-fit test with 100 parametric bootstraps (Burnham and Anderson 2002, MacKenzie et al. 2006).

\section{Broadcast Experiment}

Because survey interval length was tightly linked to use of the broadcast in our experimental design (see above), we were not able to disentangle the effects of broadcast and interval length in an occupancy modeling frameworkUNMARKED does not have such flexibility (R. Chandler personal communication). Therefore, to gain insight into how behavioral response to broadcast vocalizations may affect detectability, we used counts of five behaviors (i.e. flew toward observer, song, calls, perched, flew away from observer) recorded during each survey interval to run generalized linear models in Program $\mathrm{R}$ with the deviance distributed as chi-square and an offset that accounts for the difference in survey interval length. We tested the null hypotheses that behavioral counts in the prebroadcast interval were no different from those in the duringbroadcast and postbroadcast intervals. To avoid potential pseudoreplication of individuals, we included only the first survey per wetland in which we detected the species. Results are presented as means $\pm \mathrm{SE}$.

\section{RESULTS}

\section{Detectability}

The best-fit model for detectability $(-2 \log$-likelihood $=$ 495.6, number of parameters $K=8$, AIC $=511.6)$ included the variables WIND $(\beta=-0.36 \pm 0.20)$, DATE $(\beta=-5.3 \pm$ $1.2)$, BROADCAST $\left(\beta_{\text {before }}=[\right.$ no estimate; reference category], $\beta_{\text {during }}=-0.61 \pm 0.39, \beta_{\text {after }}=0.75 \pm 0.35$ ), and an intercept $(\beta=7.8 \pm 1.9)$. The best-fit model performed far better than any other model $\left(w_{i}=0.99\right)$, and no other models received substantial support $(\Delta \mathrm{AIC}>9)$. In the best-fit model, absolute levels of detection before, during, and after broadcast (not corrected for interval length) were $0.28 \pm 0.06,0.18 \pm 0.05$, and $0.45 \pm 0.07$, respectively. Detectability decreased steeply throughout the season, with surveys in early May nearly $4 \times$ more likely to detect a Rusty Blackbird than those in late June (Figure 4A). Predictably, detectability decreased steadily with wind speed (Figure 4B). Post hoc models including interaction terms did not outperform the additive best-fit detectability model. Although we suspected that detectability was lowest during midseason, we found no evidence to support those suspicions, in that the quadratic model $\left(\mathrm{DATE}^{2}\right)$ received considerably less support than the univariate model with DATE. Contrary to earlier results using naive detections (Powell 2008), our approach found no evidence that time of day affected detectability $(\Delta$ AIC $>32)$. We estimated a mean detectability of $0.29 \pm 0.04 \quad(95 \%$ confidence interval [CI]: $0.22-0.37$ ); in other words, given that a site was occupied, we detected one or more Rusty Blackbirds in $\sim 3$ out of 10 surveys. A goodness-of-fit test indicated that our global model fit the data $(P=0.14)$, and post hoc models that included an interaction term did not outperform the best-fit model $(\Delta \mathrm{AIC}>4)$.

\section{Occupancy}

We detected Rusty Blackbirds in 46 of the 546 wetlands surveyed during 2006 and 2007 (naive occupancy $=0.084$ ). The best-fit model for occupancy included the variables SOFTWOOD_UP, BEAVER, and PUDDLES (Tables 3 and 4). SOFTWOOD_UP was included in only the top five models (Table 3), and sites with $>70 \%$ softwoods in the upland were about twice as likely to be occupied by Rusty Blackbirds (Figure 5). Age of softwoods was considerably less important: the 11 models that included YNGSF or HARVEST5to15 received little support (Table 3). PUDDLES was included in the top six models because Rusty Blackbirds were more than $4 \times$ more likely to be found at sites with independent shallow water than those without (Figure 5). MUD, however, was a poor predictor of foraging habitat; models that included this variable received little support (Table 3). Wetlands with evidence of beaver activity were positively correlated with Rusty 

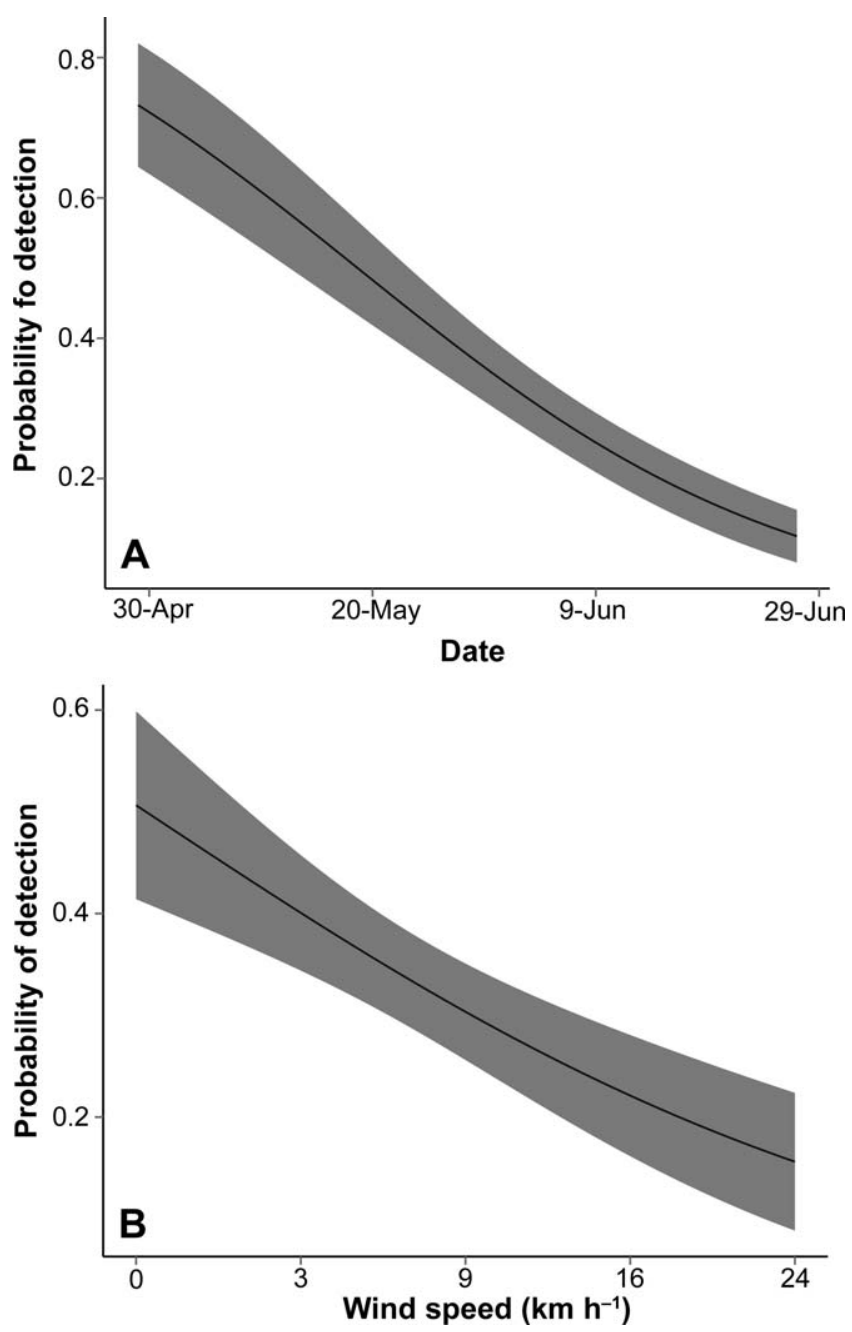

FIGURE 4. Estimated probability of detection ( \pm SE) of Rusty Blackbirds in Maine and Vermont, USA, 2006-2007, over the course of the season (A) and with increasing wind speed (B), as generated from the best-fit model for detectability. Scale on $x$ axis in (B) is not linear, because it is based on nonlinear ordinal categories of wind speed (see Table 1).

Blackbird occupancy; BEAVER appeared in three of the five best-fit models. Further, removing BEAVER from the best-fit model decreased model fit $(\triangle \mathrm{AIC}=2.6$; Table 3$)$, and wetlands with BEAVER were twice as likely to be occupied by Rusty Blackbirds as those without (Figure 5). The univariate model with BEAVER was only marginally better than the null model, suggesting that Rusty Blackbird occupancy cannot be explained by the presence of beavers alone. To confirm, post hoc, that CHOICE was an appropriate variable to include in the base model, we ran the best-fit model without CHOICE-predictably, model fit suffered $(\triangle \mathrm{AIC}=1.6)$ despite the steep penalty $(+6)$ imposed by AIC for including this three-category variable. Wetlands occupied in previous seasons were more than twice as likely to be occupied, compared with sites selected from the literature or using stratified random design (Figure 5). Further, $\mathrm{CHOICE}_{\text {old }+}$ wetlands (those that were occupied in previous years) were more than twice as likely to be occupied, compared with wetlands chosen by other means (Figure 5). Adding YEAR to the best-fit model decreased model fit $(\triangle \mathrm{AIC}=1.2)$, the parameter estimate for YEAR ( $\beta=0.41 \pm 0.46)$ was imprecise, and estimates showed practically no difference in occupancy between years (Figure 5), providing no substantial evidence that YEAR affected occupancy; thus, we made the simplifying assumption that the population was closed to changes in occupancy between 2006 and 2007. Although we detected one or more Rusty Blackbirds in only 1 of 78 wetlands smaller than 0.1 ha, the categorical variable WETAREA as a whole did not receive strong support $\left(\sum w_{i}=0.08\right)$; however, predicted probabilities suggest that wetlands smaller than 0.5 ha were less likely to be occupied than larger wetlands (Figure 5). Adding ROAD to the best-fit model decreased model fit $(\triangle \mathrm{AIC}=6.3)$, providing essentially no evidence that relatively large roads had a negative impact on Rusty Blackbird occupancy. Contingent on our detectability analysis, mean wetland occupancy was $0.12 \pm 0.02$ (95\% CI: 0.08-0.18), which applies only to the wetlands we surveyed in the present study. In other words, when we considered birds that were present but not detected, $\sim 12 \%$ of surveyed wetlands were occupied. Sites selected using stratified random design were marginally less likely to be occupied $\left(\mathrm{CHOICE}_{\text {Random: }} 0.07 \pm 0.02\right.$, 95\% CI: 0.03-0.11) than those selected in the field on the basis of literature and our experience $\left(\mathrm{CHOICE}_{\mathrm{Literature}}\right.$ : $0.10 \pm 0.01,95 \%$ CI: 0.07-0.13; Figure 5).

\section{Broadcast Experiment}

After correcting for survey length, we found that during wetland surveys, Rusty Blackbirds flew toward the observer and perched significantly more during the broadcast than before the broadcast $(P<0.001$; Figure 6). Rusty Blackbirds also flew toward the observer marginally more in the postbroadcast interval than in the prebroadcast interval $(P<0.06)$; no other comparisons were significantly different.

\section{DISCUSSION}

\section{Habitat Occupancy}

The availability of Rusty Blackbird nesting habitat positively influenced occupancy-specifically when trees in the adjacent uplands were $\geq 70 \%$ softwoods. In New England, most (62 of 65) documented Rusty Blackbird nests were placed in conifers (Kennard 1920, Ellison 1990, Powell et al. 2010b), and many nests in our study were in dense balsam fir 1-3 $\mathrm{m}$ high (Powell et al. 2010b). Comparatively, in coastal Alaska and Canada, most nests were placed in small spruce (Picea sp.) trees, but in interior 
TABLE 3. Akaike's Information Criterion (AIC) $)^{\text {a }}$ model selection results for models predicting wetland occupancy ( $\psi$ ) of Rusty Blackbirds in Maine and Vermont, USA, 2006-2007.

\begin{tabular}{|c|c|c|c|c|c|}
\hline Model & -2 Log-likelihood & $K^{a}$ & AIC & $\Delta \mathrm{AIC}$ & $w_{i}$ \\
\hline$\psi(\text { SOFTWD_UP }+ \text { BEAVER }+ \text { PUDDLES })^{\mathrm{b}}$ & 471.7 & 11 & 493.7 & 0.0 & 0.47 \\
\hline$\psi($ SOFTWD_UP + BEAVER + PUDDLES + YEAR) & 470.9 & 12 & 494.9 & 1.2 & 0.26 \\
\hline$\psi($ SOFTWD_UP + PUDDLES) & 476.2 & 10 & 496.2 & 2.6 & 0.13 \\
\hline$\psi($ SOFTWD_UP + PUDDLES + WETAREA $)$ & 471.4 & 13 & 497.4 & 3.7 & 0.07 \\
\hline$\psi($ SOFTWD_UP + BEAVER + PUDDLES + ROAD $)$ & 469.9 & 15 & 499.9 & 6.3 & 0.02 \\
\hline$\psi($ PUDDLES + YNGSF) & 480.8 & 10 & 500.8 & 7.1 & 0.01 \\
\hline$\psi($ MUD + HARVEST5TO15) & 481.0 & 10 & 501.0 & 7.3 & 0.01 \\
\hline$\psi($ PUDDLES + YNGSF + YEAR) & 479.2 & 11 & 501.2 & 7.5 & 0.01 \\
\hline$\psi($ WETAREA + MUD + BEAVER) & 476.3 & 13 & 502.3 & 8.7 & 0.01 \\
\hline$\psi(Y N G S F+M U D)$ & 483.0 & 10 & 503.0 & 9.4 & 0.00 \\
\hline$\psi($ WETAREA + HARVEST5TO15) & 480.3 & 12 & 504.3 & 10.7 & 0.00 \\
\hline$\psi($ YNGSF + MUD + YEAR) & 482.8 & 11 & 504.8 & 11.1 & 0.00 \\
\hline$\psi($ BEAVER + YNGSF $)$ & 487.3 & 10 & 507.3 & 13.7 & 0.00 \\
\hline$\psi($ MUD + HARVEST5TO15 + YEAR) & 489.1 & 10 & 509.1 & 15.5 & 0.00 \\
\hline$\psi($ BEAVER) & 491.8 & 9 & 509.8 & 16.1 & 0.00 \\
\hline$\psi(\cdot)$ & 495.6 & 8 & 511.6 & 18.0 & 0.00 \\
\hline
\end{tabular}

${ }^{a} K$ is number of parameters; $\triangle \mathrm{AIC}$ is difference in AIC in relation to the most parsimonious value; $w_{i}$ is Akaike weight.

${ }^{b}$ Base model for all models shown: $\psi($ CHOICE), $p$ (WIND + DATE + BROADCAST), where $p$ denotes detectability.

Alaska, most nests were in willows (Salix sp.), which suggests some flexibility with respect to nest-site selection (Matsuoka et al. 2010b). We detected Rusty Blackbirds in wooded fens, in wetlands adjacent to mature coniferous forest, and in wetlands adjacent to 10 - to 15 -year-old clearcuts, which suggests that the species is also somewhat flexible with respect to selection at the wetland scale. Although most nests found in our study area were in thick

TABLE 4. Model-averaged parameter estimates, standard errors, and $95 \%$ confidence intervals $(\mathrm{Cl})$ for models describing occupancy of Rusty Blackbirds in Maine and Vermont, USA, 2006-2007.

\begin{tabular}{|c|c|c|}
\hline Covariate & Estimate & $95 \% \mathrm{Cl}$ \\
\hline \multicolumn{3}{|l|}{ Habitat occupancy } \\
\hline $\mathrm{CHOICE}_{\mathrm{Old}+}{ }^{\mathrm{a}}$ & 1.20 & 0.23 to 2.17 \\
\hline $\mathrm{CHOICE}_{\text {Random }}$ & -0.35 & -1.30 to 0.59 \\
\hline PUDDLES & 1.97 & 0.73 to 3.21 \\
\hline BEAVER & 0.88 & 0.10 to 1.67 \\
\hline SOFTWD_UP & 1.06 & 0.32 to 1.80 \\
\hline WETAREA $_{0.1-0.5 \mathrm{ha}}$ & 0.18 & -1.52 to 1.88 \\
\hline WETAREA $_{0.6-2 \mathrm{ha}}$ & 1.17 & -0.38 to 2.72 \\
\hline WETAREA $_{>2 \text { ha }}$ & 0.86 & -0.76 to 2.49 \\
\hline YEAR & 0.35 & -0.53 to 1.23 \\
\hline \multicolumn{3}{|l|}{ Detection probability } \\
\hline DATE & -5.13 & -7.43 to -2.84 \\
\hline BROADCAST $_{\text {during }}{ }^{a}$ & -0.54 & -1.26 to 0.18 \\
\hline BROADCAST $_{\text {after }}$ & 0.72 & 0.06 to 1.37 \\
\hline WIND & -0.33 & -0.71 to 0.06 \\
\hline
\end{tabular}

${ }^{a}$ Categories $\mathrm{CHOICE}_{\text {Literature }}$ and BROADCAST before $_{\text {do not have }}$ parameter estimates because they are reference categories. $\mathrm{CHOICE}_{\text {Driveby }}$ is not shown because occupancy was fixed at 1.0 for those six observations. Absolute levels of occupancy or detectability for those categories are presented in Results. young conifers regenerating from timber harvests (Powell et al. 2010b), and Rusty Blackbirds in New Hampshire may select for young coniferous regrowth at the landscape scale (P. Newell and C. Foss personal communication), occupancy at the wetland scale was apparently not influenced by age of coniferous growth. In contrast to the results of a previous analysis (Powell 2008), YNGSF and HARVEST5to15 were poor predictors of occupancy at the wetland scale, providing no evidence that Rusty Blackbirds in our study area select wetlands solely on the basis of young coniferous growth either within or adjacent to the wetlands; rather, they appeared to select wetlands sur-

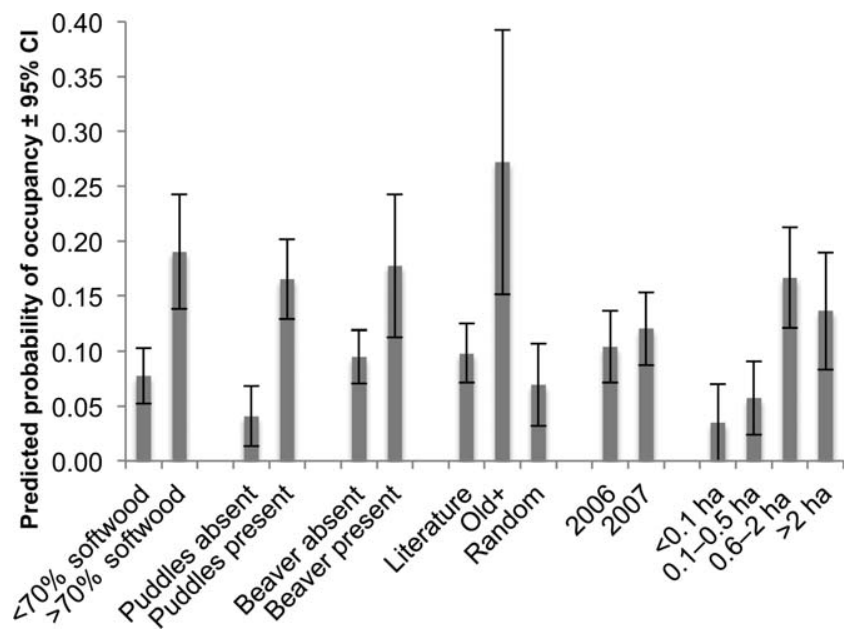

FIGURE 5. Mean predicted probabilities of occupancy for Rusty Blackbirds in Maine and Vermont, USA, as described by six explanatory variables, from left to right: SOFTWOOD_UP, PUDDLES, BEAVER, CHOICE, YEAR, and WETAREA. 


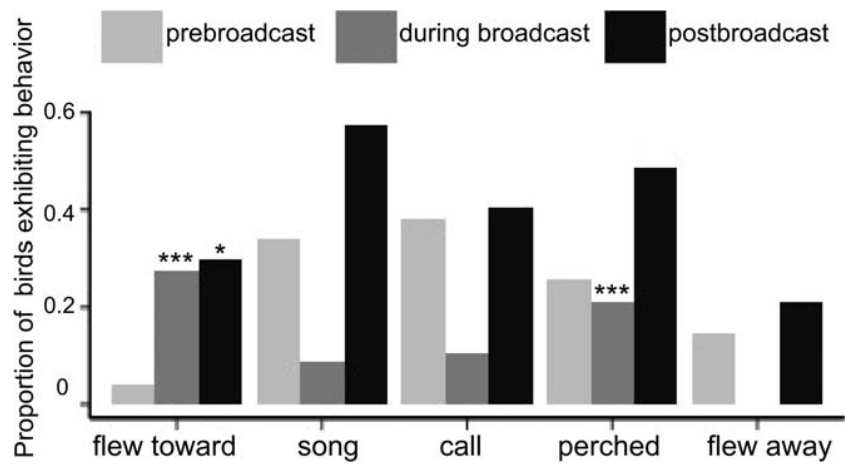

FIGURE 6. Behavioral responses of Rusty Blackbirds $(n=47)$ prior to (3 min), during (38 s), and after (5 min) broadcast of Rusty Blackbird vocalizations in Maine and Vermont, USA, 20062007. Symbols indicate significant difference from prebroadcast period, correcting for difference in period length, at $P<0.1\left(^{*}\right)$ and $P<0.001\left(^{* * *}\right)$. Proportions shown are not corrected for period length.

rounded by conifers, regardless of age. In the absence of timber harvests, Rusty Blackbirds may be content to nest in naturally stunted conifers such as those found in bogs and fens or in small patches of regenerating coniferous growth created by beavers or resulting from windthrow (Kennard 1920, Ellison 1990).

Although the species frequently nests in short coniferous growth, regenerating clear-cuts adjacent to wetlands may attract Rusty Blackbirds into uplands where their nests are subject to higher predation risk (Powell et al. 2010b) and, possibly, ecological traps (Robertson and Hutto 2006). That Rusty Blackbirds do not appear to target regenerating conifer stands at the wetland scale is thus significant. We suspect that in the early spring, individuals returning to breeding grounds select habitat at multiple scales, targeting landscapes with wetlands surrounded by at least some short coniferous growth that contain cues indicating good foraging habitat, such as shallow water with high invertebrate biomass. After pairing, females probably select nest sites in the thickest coniferous growth that are often (but not always) near wetlands (Ellison 1990, Matsuoka et al. 2010b, Powell et al. 2010b, Buckley 2013).

Rusty Blackbirds forage in shallow water, where they probe for aquatic prey in leaf litter (Bent 1958, Ellison 1990, Avery 1995). We strongly suspect that the area of shallow water $(<6 \mathrm{~cm}$ deep) is an important driver of habitat selection, but due to logistical constraints we were unable to quantify the availability of shallow water at each wetland, and instead used MUD and PUDDLES as proxies. PUDDLES was a strong predictor of occupancy and was generally indicative of shallow water, which we believe is ideal foraging habitat for Rusty Blackbirds. Shallow water unconnected to flowing tributaries often teems with prey items (e.g., tadpoles and Odonates; L. Powell personal observation), presumably because of a lack of predatory fish and evaporation by seasonal drying. We believe that amphibian eggs and larvae, as well as invertebrate larvae, likely provide an easily accessed, calorie-rich food source in sites with shallow water; this warrants further investigation. Unlike PUDDLES, MUD was a poor predictor of occupancy. Although we observed Rusty Blackbirds foraging on mud, the presence of mud likely indicates a recent lowering of the water table (e.g., failed beaver dam, rapid seasonal drying) but appears to be less indicative than shallow water of quality foraging conditions. The amount of shallow water varies both within and among years, but it remains unclear how seasonal variations in rainfall affect occupancy, colonization, or extinction of suitable habitat on the breeding grounds. To better understand the dynamic nature of rainfall and hydrology on Rusty Blackbird occupancy, future efforts could design studies similar to that of DeLeon (2012), who used repeated site visits to model the effect of shallow water on occupancy of wintering Rusty Blackbirds both within and among years. Furthermore, future research could aid management efforts by understanding the scale of selection for shallow water. For example, do Rusty Blackbirds select breeding habitat on the basis of general abundance of surface water on the landscape (Matsuoka et al. 2010a) or the prevalence of shallow water at small spatial scales?

American beavers probably create both foraging and nesting habitat for Rusty Blackbirds, and our data correspondingly suggest that beaver presence increases the probability of occupancy when nesting and foraging habitat are already present. Beavers selectively remove hardwoods, which increases light gaps and encourages growth of nonpreferred trees such as spruces (Johnston and Naiman 1990). McDowell and Naiman (1986) found that beavers increase the density of coarse particulate organic matter and the biomass of invertebrates by $2-5$ times, and beavers specifically increased the abundance of four of the Rusty Blackbird's prey items: dragonflies (Odonata), damselflies (Odonata), caddisflies (Trichoptera), and snails (Gastropoda; Avery 1995, Harthun 1999). Beavers may facilitate Rusty Blackbird habitat use by augmenting nesting and foraging habitat, so a logical next step would be to test the hypothesis that active beaver control (e.g., beaver exclusion devices, trapping, lethal control; all common practices in New England) has a negative impact on Rusty Blackbirds. Further, it remains unclear which stage(s) of beaver colonization or abandonment offer the most Rusty Blackbird foraging and nesting habitat.

\section{Detectability}

Accounting for heterogeneous detectability is essential to generating unbiased estimates of habitat occupancy (MacKenzie et al. 2003). Detectability decreased with 
increasing wind speed and decreased steeply over the course of the season (Figure 4). Mean detectability of Rusty Blackbirds was 0.29 , so about two thirds of surveys at occupied wetlands produced nondetections. Our estimates of detectability were considerably lower than estimates from Alaska using line transects (Machtans et al. 2007) or area searches (Matsuoka et al. 2010a), presumably because of the relative scarcity of the species in our study areas. Given that Rusty Blackbirds in New England often used multiple noncontiguous wetlands $(=2.8 \pm 0.4$ wetlands) within relatively large home ranges (Powell et al. 2010a), perhaps it is not surprising that detectability from single survey points at one wetland was low. Two scenarios could have produced false absences during surveys: either individual(s) were nearby and heard the broadcast but remained inconspicuous, or they responded and we failed to see or hear their response. Wind decreased our ability to detect Rusty Blackbirds, probably by (1) limiting our ability to hear singing birds; (2) discouraging birds from flying, thus decreasing our probability of detecting them visually; and (3) limiting the birds' ability to hear the broadcast. Male Rusty Blackbirds often responded aggressively to our broadcast by performing song spread displays (Orians and Christman 1968) interspersed with short flights to perches that encircled the source of the broadcast (L. Powell and T. Hodgman personal observation). The species is about $4 \times$ easier to detect early in the season, which probably corresponds to the egg-laying period (about early to midMay; Matsuoka et al. 2010b), when males aggressively defend females and territories. On the basis of adults' aggressive defense of fledglings and older chicks (Powell 2008), we suspected that detectability would increase again toward the end of the season, but we found no evidence to support this hypothesis. Buckley (2013) noted behavioral differences between years and suggested that these differences resulted from changes in the abundance of a predator, the red squirrel (Tamiascuiurus hudsonicus); perhaps these behavioral differences also affect detectability. Because we had relatively few midday detections in 2006 (Powell 2008), we concentrated our surveys in the early morning and late afternoon in 2007; however, the fact that few wetlands were repeatedly surveyed during midday almost certainly contributed to the lack of support for detectability models that included time of day. Future surveys should take a more systematic approach in analyzing the importance of time of day on detectability, because we cannot rule out the hypothesis that early mornings have the highest detectability.

\section{Broadcast Experiment}

Including BROADCAST clearly improved the fit of detectability models, indicating that the combined effects of a broadcast and survey length affected detectability. Even without correcting for interval length, the effect of the broadcast was obvious: during 38-s broadcast intervals, Rusty Blackbirds flew toward observers $6 \times$ more often than during 3-min prebroadcast intervals (Figure 6). Qualitatively, Rusty Blackbirds appeared to be aggressive to the broadcast, singing and performing song-spread displays (Orians and Christman 1968, Avery 1995) as they circled the observer, particularly early in the season. Given the combined low abundance and low detectability, a simple and time-efficient technique such as a brief broadcast can improve efforts to monitor this species.

\section{Recommendations for Monitoring}

The substantial challenges of studying this species' breeding biology include remote and often inaccessible breeding habitat, low abundance and detectability, and a population that may continue to decline. Quantitative information on occupancy or detectability would greatly improve selection of sites for monitoring and would be consistent across broad geographic areas, thus increasing power to detect population (e.g., occupancy) trends. Our study provides robust estimates of occupancy and detectability using several different site-selection techniques, along with parameter estimates quantifying the effects of site and sampling variables on occupancy and detectability of the species. Researchers can use these findings collectively to help design an efficient monitoring plan for the species (e.g., Powell 2009). For example, with mean estimates of occupancy and detectability, researchers can determine the number of wetlands and number of repeat surveys that maximize statistical precision (e.g., MacKenzie and Royle 2005). Specifically, researchers can increase detectability of Rusty Blackbirds by (1) broadcasting a conspecific vocalization, (2) avoiding windy days (especially $>25 \mathrm{~km} \mathrm{~h}^{-1}$ ), and (3) concentrating surveys early in the season (i.e. early May in our study areas, depending on road conditions). Given the inability of UNMARKED to adjust to unequal interval lengths within surveys, we recommend that future technicians independently record blackbird detections within 1-min intervals for the duration of the survey (e.g., Powell 2009). This would effectively increase sample size for estimating detectability and allow researchers to disentangle the effects of survey interval length and use of a broadcast. Further, researchers should also adjust the broadcast interval length to $1 \mathrm{~min}$ while making special note of new detections from 39 to $60 \mathrm{~s}$ so that future surveys can be compared to the $1,000+$ surveys performed to date using the 3-min/38-s/5-min protocol (L. Powell personal observation).

Given our results, biologists can now systematically focus their site selection on wetlands most likely to be occupied by Rusty Blackbirds: wetlands of various types containing areas of shallow water (e.g., beaver-created flowages, seeps, peatlands) with dense softwoods nearby, 
including those previously occupied by the species. Wetlands larger than 0.5 ha (as estimated on the ground) appear more likely to be occupied than smaller wetlands (Figure 5); future surveys should consider this during design and planning, and consider estimating wetland size remotely (e.g., satellite imagery, aerial photographs) if possible. Given recent advances in occupancy modeling (especially in UNMARKED), we believe that a welldesigned, multiseason occupancy model can provide rich insights into how habitat change and colonizationextinction dynamics interact to affect trends in Rusty Blackbird occupancy over time. Further, with the insights into habitat occupancy and detectability we provide here, monitoring efforts can be streamlined-a critical first step toward ensuring that Rusty Blackbirds continue to breed in northern New England.

\section{ACKNOWLEDGMENTS}

We thank C. M. Fisher, H. Hermann, C. Holmberg, R. T. Jones, and particularly J. D. Osenton for their tireless work as field technicians. We are indebted to W. Halteman, M. D. Kaller, and J. A. Royle for their statistical guidance and to D. M. Ellis, T. U. Powell, and B. Tyne for contributions in the field. The Maine Warden Service, Pittston Farms, and the Foleys provided critical logistical support. We thank M. J. Chamberlain, E. E. DeLeon, R. L. Holberton, C. S. Loftin, S. M. Matsuoka, C. Lindell, P. Newell, P. C Stouffer, and several anonymous reviewers for insightful comments on the manuscript. This project was carried out in association with the International Rusty Blackbird Working Group and funded by the Maine Department of Inland Fisheries and Wildlife via Federal Aid in Wildlife Restoration, the Maine Outdoor Heritage Fund, and the University of Maine Graduate Student Government. We dedicate this paper to the memory of Russ Greenberg.

\section{LITERATURE CITED}

Atwood, J. L., C. C. Rimmer, K. P. McFarland, S. H. Tsai, and L. R. Nagy (1996). Distribution of Bicknell's Thrush in New England and New York. Wilson Bulletin 108:650-661.

Avery, M. L. (1995). Rusty Blackbird (Euphagus carolinus). In The Birds of North America 200 (A. Poole and F. Gill, Editors). Academy of Natural Sciences, Philadelphia, and American Ornithologists' Union, Washington DC, USA. pp. 1-16.

Beecher, W. J. (1951). Adaptations for food-getting in the American blackbirds. The Auk 68:411-440.

Bent, A. C. (1958). Life histories of North American blackbirds, orioles, tanagers, and allies. United States National Museum Bulletin 211.

Buckley, S. H. (2013). Rusty Blackbirds in Northeastern Industrial Forests: A multi-scale study of nest habitat selection and nest survival. M.S. thesis, SUNY College of Environmental Sciences and Forestry, Syracuse, NY, USA.
Burnham, K. P., and D. R. Anderson. (2002). Model Selection and Multimodel Inference: A Practical Information-Theoretic Approach, 2nd ed. Springer-Verlag, New York, NY, USA.

Carter, M. F., W. C. Hunter, D. N. Pashley, and K. V. Rosenberg (2000). Setting conservation priorities for landbirds in the United Sates: The Partners in Flight approach. The Auk 117: 541-548.

Cowardin, L. M., V. Carter, F. C. Golet, and E. T. LaRoe (1979). Classification of wetlands and deepwater habitats of the United States. U.S. Fish and Wildlife Service, Washington DC, USA.

DeLeon, E. E. (2012). Ecology of Rusty Blackbirds wintering in Louisiana: Seasonal trends, flock composition and habitat associations. M.S. thesis, Louisiana State University, Baton Rouge, LA, USA.

Edmonds, S. T., D. C. Evers, D. A. Cristol, C. Mettke-Hofmann, L. L. Powell, A. J. McGann, J. W. Armiger, O. P. Lane, D. F. Tessler, P. Newell, K. Heyden, and N. J. O'Driscoll (2010). Geographic and seasonal variation in mercury exposure of the declining Rusty Blackbird. The Condor 112:789-799.

Ellison, W. G. (1990). The status and habitat of the Rusty Blackbird in Caledonia and Essex counties. Vermont Fish and Widlife Department, Woodstock, VT, USA.

Erskine, A. J. (1977). Birds in boreal Canada: Communications, densities, and adaptations. Canadian Wildlife Service Report Series 41.

Erskine, A. J. (1992). Atlas of Breeding Birds of the Maritime Provices. Nova Scotia Museum, Halifax, NS, Canada.

Fiske, I. J., and R. Chandler (2010). Unmarked: Models for Data from Unmarked Animals. R package version 0.8-1. http:// CRAN.R-project.org/package= unmarked.

Foss, C. R. (Editor) (1995). Atlas of Breeding Birds in New Hampshire. Arcadia, Dover, NH, USA.

Greenberg, R., D. W. Demarest, S. M. Matsuoka, C. MettkeHofmann, D. Evers, P. B. Hamel, J. Luscier, L. L. Powell, D. Shaw, M. L. Avery, K. A. Hobson, P. J. Blancher, and D. K. Niven (2011). Understanding declines in Rusty Blackbirds. In Boreal Birds of North America: A Hemispheric View of Their Conservation Links and Significance (J. V. Wells, Editor). Studies in Avian Biology 41:107-126.

Greenberg, R., and S. Droege (1999). On the decline of the Rusty Blackbird and the use of ornithological literature to document long-term population trends. Conservation Biology $13: 553-559$.

Greenberg, R., C. Elphick, J. Nordby, C. Gjerdrum, H. Spautz, W. G. Shriver, B. Schmeling, B. Olsen, P. Marra, N. Nur, and M. Winter (2006). Flooding and predation: Trade-offs in the nesting ecology of tidal-marsh sparrows. In Terrestrial Vertebrates of Tidal Marshes: Evolution, Ecology, and Conservation (R. Greenberg, J. E. Maldonado, S. Droege, and M. V. McDonald, Editors). Studies in Avian Biology 32:96109.

Greenberg, R., and S. M. Matsuoka (2010). Rusty Blackbird: Mysteries of a species in decline. The Condor 112:770-777.

Harthun, M. (1999). The influence of the European beaver (Castor fiber albicus) on the biodiversity (Odonata, Mollusca, Trichoptera, Ephemeroptera, Diptera) of brooks in Hesse (Germany). Limnologica 29:449-464.

Hodgman, T. P., and H. L. Hermann (2003). Rusty Blackbird. In A Survey of Rare, Threatened, and Endangered Fauna in Maine: St. John Uplands and Boundary Plateau (2001-2002) (H. L. 
Hermann, T. P. Hodgman, and P. deMaynadier, Editors). Maine Department of Inland Fisheries and Wildlife, Bangor, ME, USA. pp. 65-72.

Johnston, C. A., and R. J. Naiman (1990). Browse selection by beaver: Effects on riparian forest composition. Canadian Journal of Forest Research 20:1036-1043.

Kennard, F. H. (1920). Notes on the breeding habits of the Rusty Blackbird in northern New England. The Auk 37:412-422.

Klein, E., E. E. Berg, and R. Dial (2005). Wetland drying and succession across the Kenai Peninsula Lowlands, southcentral Alaska. Canadian Journal of Forest Research 35: 1931-1941.

Laughlin, S. B., and D. P. Kibbe (Editors) (1985). The Atlas of Breeding Birds of Vermont. University Press of New England, Hanover, NH, USA.

Machtans, C. S., S. L. Van Wilgenburg, L. A. Armer, and K. A. Hobson (2007). Retrospective comparison of the occurrence and abundance of Rusty Blackbird in the Mackenzie Valley, Northwest Territories. Avian Conservation and Ecology 2:3.

MacKenzie, D. I., J. D. Nichols, J. E. Hines, M. G. Knutson, and A. B. Franklin (2003). Estimating site occupancy, colonization, and local extinction when a species is detected imperfectly. Ecology 84:2200-2207.

MacKenzie, D. I., J. D. Nichols, G. B. Lachman, S. Droege, J. A. Royle, and C. A. Langtimm (2002). Estimating site occupancy rates when detection probabilities are less than one. Ecology 83:2248-2255.

MacKenzie, D. I., J. D. Nichols, J. A. Royle, K. H. Pollock, L. L. Bailey, and J. E. Hines (2006). Occupancy Estimation and Modeling: Inferring Patterns and Dynamics of Species Occurrence. Academic Press, Burlington, MA, USA.

MacKenzie, D. I., and J. A. Royle (2005). Designing occupancy studies: General advice and allocating survey effort. Journal of Applied Ecology 42:1105-1114.

Matsuoka, S. M., D. Shaw, and J. A. Johnson (2010a). Estimating the abundance of nesting Rusty Blackbirds in relation to wetland habitats in Alaska. The Condor 112:825-833.

Matsuoka, S. M., D. Shaw, P. H. Sinclair, J. A. Johnson, R. M. Corcoran, N. C. Dau, P. M. Meyers, and N. A. Rojek (2010b). Nesting ecology of the Rusty Blackbird in Alaska and Canada. The Condor 112:810-824.

McDowell, D. M., and R. J. Naiman (1986). Structure and function of a benthic invertebrate stream community as influenced by beaver (Castor canadensis). Oecologia 68:481-489.

Niven, D. K., J. R. Sauer, G. S. Butcher, and W. A. Link (2004). Christmas Bird Count provides insights into population change in land birds that breed in the boreal forest. American Birds 58:10-20.

Orians, G. H., and G. M. Christman (1968). A comparative study of the behavior of Red-winged, Tricolored, and Yellow-headed blackbirds. University of California Publications in Zoology 84: $1-81$.

Peterson, J. M. C. (1988). Rusty Blackbird, Euphagus carolinus. In The Atlas of Breeding Birds in New York State (R. F. Andrle and J. R. Carroll, Editors). Cornell University Press, Ithaca, NY, USA.

Powell, L. L. (2008). Habitat occupancy, status, and reproductive ecology of Rusty Blackbirds in New England. M.S. thesis, University of Maine, Orono, ME, USA.

Powell, L. L. (2009). Long-term monitoring plan for Rusty Blackbirds in the Atlantic northern forest, version 1.8. University of Maine, Orono, ME, USA.
Powell, L. L., T. P. Hodgman, and W. E. Glanz (2010a). Home ranges of Rusty Blackbirds breeding in wetlands: How much would buffers from timber harvest protect habitat? The Condor 112:834-840.

Powell, L. L., T. P. Hodgman, W. E. Glanz, J. D. Osenton, and C. M. Fisher (2010b). Nest-site selection and nest survival of the Rusty Blackbird: Does timber management adjacent to wetlands create ecological traps? The Condor 112:800-809.

R Development Core Team (2009). R version 2.10.0: A Language and Environment for Statistical Computing. R Foundation for Statistical Computing, Vienna, Austria. http://www.R-project. org.

Rich, T. D., C. J. Beardmore, H. Berlanga, P. J. Blancher, M. S. W. Bradstreet, G. S. Butcher, D. Demarest, E. H. Dunn, W. C. Hunter, E. Iñigo-Elias, J. A. Kennedy, A. Martell, et al. (2004). Partners in Flight: North American Landbird Conservation Plan. Partners in Flight, Cornell Laboratory of Ornithology, Ithaca, NY, USA.

Robbins, C. S., J. W. Fitzpatrick, and P. B. Hamel (1992). A warbler in trouble: Dendroica cerulea. In Ecology and Conservation of Neotropical Migrant Landbirds (J. M. Hagan III and D. W. Johnston, Editors). Smithsonian Institution Press, Washington DC, USA. pp. 549-562.

Robertson, B. A., and R. L. Hutto (2006). A framework for understanding ecological traps and an evaluation of existing evidence. Ecology 87:1075-1085.

Rosenberg, K. V., S. Barker Swarthout, and R. S. Hames (2008). Cerulean Warbler Conservation Initiative: Breeding Ground Surveys, 2003-2007. Final Report to the National Council for Air and Stream Improvement and the National Fish and Wildlife Foundation.

Sauer, J. R., and S. Droege (1992). Geographic patterns in population trends of Neotropical migrants in North America. In Ecology and Conservation of Neotropical Migrant Landbirds (J. M. Hagan III and D. W. Johnston, Editors). Smithsonian Institution Press, Washington DC, USA. pp. 2642.

Sauer, J. R., J. E. Hines, and J. Fallon (2004). The Christmas Bird Count home page. Version 2004.1. U.S. Geological Survey Patuxent Wildlife Research Center, Laurel, MD, USA. http:// www.mbr-pwrc.usgs.gov/bbs/cbc.html. Accessed February 2008.

Sauer, J. R., J. E. Hines, and J. Fallon (2005). The North American Breeding Bird Survey, Results and Analysis 1966-2005. Version 6.2.2006. U.S. Geological Survey Patuxent Wildlife Research Center, Laurel, MD, USA. http://www.mbr-pwrc. usgs.gov/bbs/bbs.html.

Townsend, J. M., C. C. Rimmer, and K. P. McFarland (2009). Investigating the limiting factors of a rare, vulnerable species: Bicknell's Thrush. In Proceedings of the Fourth International Partners in Flight Conference: Tundra to Tropics (T. D. Rich, C. Arizmendi, D. Demarest, and C. Thompson, Editors). Partners in Flight, Washington DC, USA. pp. 91-95.

U.S. NABCI Committee (2000). The North American Bird Conservation Initiative in the United States: A Vision of American Bird Conservation. U.S. Fish and Wildlife Service, Division of North American Waterfowl and Wetlands, Arlington, VA, USA. 